\title{
高曲げ強度セメント・モルタルの研究
}

(調合方法と諸物性に関する研究)

\section{STUDY ON THE MIXING PROPORTIONS OF HIGH BENDING STRENGTH MORTARS AND THEIR CHARACTERISTICS}

山本康弘 ${ }^{* 1}$, 本間礼 ${ }^{* 2}$, 三田紀行*3, 斎藤 仁*4 Yasuhiro YAMAMOTO, Ayato HOMMA, Noriyuki MITA and Hitoshi SAITO

\footnotetext{
This paper is intended to study the mixing proportions of high bending strength mortars which have been developed recently and have been reported on this Transaction of AIJ No.492, 1997. 2. On this paper, the effects of the percentage of silica-fume, water binder ratio, sand binder ratio and the gain size of the sand were studied in order to grow up the bending strength of mortar.

And the characteristics of these mortars were clarified, such as young's modulus, shrinkage, absorption, shockproof and fireproof properties.
}

Keywords: high-bending strength mortar, heat curing, percentage of silica-fume,

siloxane binding, gain size, sand binder ratio

高曲げ強度モルタル、加温養生、シリカフューム添加量、シロキサン結合、粗粒事、砂結合材比

\section{1.まえがき.}

本研究はセメント系水和物の曲げ強度の向上に関する研究である。 これに関しては既報りにおいて、曲げ強度の向上方法とそれによる セメント水和物の内部組織について述べ、曲げ強度を向上するため には、モルタルにシリカフュームを添加して練り混ぜを行ったあと、 一次養生を行い、続いて二次盖生、即ち $60^{\circ} \mathrm{C}$ 程度の加温養生を行う ことによりモルタルの内部に珪酸の多量体が得られ、これらがシロ キサン結合による架橋を形成して高い曲げ強度が得られることを 示した。

本研究は、これらの研究に引き続き、このような高曲け強度を得 るためのセメント・モルタルの調合方法と、その諸物性について研 究したものである。

先ず、調合方法としては、シリカフュームの添加量、水結合材比、 砂結合材比および細骨材の粒径と粒度などと曲け強度・圧縮強度と の関係について検討した。またこれらの高曲げ強度モルタルの弾性 倸数、収縮率、吸水率、衝撃耐力および耐熱性・耐火性などについ て検封した。

表 1 使用材料

\begin{tabular}{|c|c|}
\hline セメント (C) & $\begin{array}{l}\text { 普通ポルトランドセメント } \\
\text { 低発熱セメント }\end{array}$ \\
\hline 細骨材 (S) & $\begin{array}{l}\text { 鹿島産陸砂 吸水率 } 1.51 \% \text { 、 } \\
\text { 珪砂 } 5 \text { 号、6 号、7 号 }\end{array}$ \\
\hline 混和 & シリカフューム（E社製 11940D） 比重 2.20 \\
\hline 混和 & 芳香族アミノスルホン酸系 \\
\hline
\end{tabular}

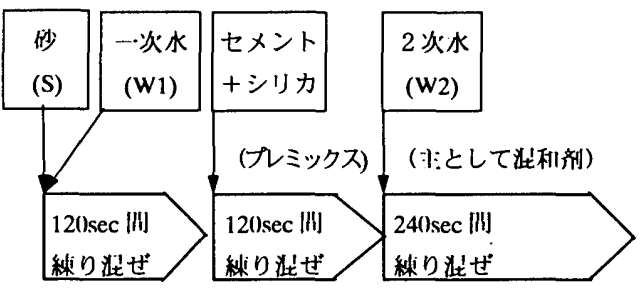

図 1 モルタルの練り混ぜ順序

表 2 一次水と二次水の割合

\begin{tabular}{|c|c|c|}
\hline 水結合材比 & 二次水 & 二次水 \\
\hline $20 \%$ 以下 & 三次水を除く全部 & 減水剤のみ $1 \%$ \\
\hline $25 \%$ & 三次水を除く全部 & 滅水剤のみ $2 \%$ \\
\hline $30 \%$ & 氷のみ $23 \%$ & 一次水を除く全部 \\
\hline
\end{tabular}

${ }^{* 1}$ 東京都立大学工学研究科建築学尃攻 教授 $\cdot$ 工博

*2 東京都立大学工学研究科建築学専攻 助手·工修

*3 職業能力開発大学校建築工学科 助手・工修

*4 東京都立大学工学研究科建築学専玫 大学院生・工修
Prof., Dept. of Architecture, Graduate School of Engineering, Tokyo Metropolitan Univ., Dr. Eng.

Research Assoc., Dept. of Architecture, Graduate School of Engineering, Tokyo Metropolitan Univ., M. Eng.

Research Assoc., Dept. of Architectural Engineering, Polytechnic Univ., M. Eng. Graduate Student, Dept. of Architecture, Graduate School of Engineering, Tokyo Metropolitan Univ., M.Eng. 


\section{2. 寒路方法}

(1) 使用材料

使用材料は表 1 に示したとおりである。セメントは $\mathrm{T} O$ 社製普通 ポルトランドセメントを、細骨材は鹿島産陸砂の $2.5 \mathrm{~mm}$ ふるいの通 過分のものを使用した。なお、これらの細骨材は湿潤状態で使用し た。また細目砂として珪砂の $5 \sim 6$ 号のものを使用した場合および 鹿島産砂と 7 号珪砂とを混合して使用した場合について検討した。 それらの性質は表 1 に示した通りである。また、混和材には $\mathrm{E}$ 社製 のシリカフュームで非顆粒のもの (11940-D) で、比表面積20万 $\mathrm{cm}^{2} / \mathrm{g}$ のものを使用した。また混和剤は $\mathrm{F}$ 社製の高性能 $\mathrm{AE}$ 减水剤 (FC-179 0）を使用した。

(2) 練り混ぜ方法

モルタルの縲り混ぜ方法は自転公転ミキサを使用し、分割緷り方 式で行った。練り混ぜ順序は図 1 のとおりである。一次水、二次水 のセメント重量に対する水と高性能 A E 減水剈の割合は表 2 に示 した通りである。また、練り混ぜ前にセメントとシリカフュームを あらかじめV型ミキサでI5分間混練した。

(3) 羡生方法

盖生方法は表 3 の通りで、打ち込み成形後から加温盖生までの一 次羑生は $20^{\circ} \mathrm{C}$ 湿空盖生で盖生期間は 1 日または 2 日間行い、それに 続く二次養生は $60^{\circ} \mathrm{C}$ の加温盖生で 3 日または 6 日間の期間行った。 その後の後養生は $20 \mathrm{C}$ の水中で強度試験材齡まで養生した。なお乾 燥収縮試験の場合は二次養生のあ之温度 $20{ }^{\circ} \mathrm{C}$, 湿度 $60 \%$ の恒温 恒湿室で養生を行った。

(4) 試験方法

\section{(i) フロー試験}

モルタルの流動性はセメントの物理試験方法(JIS R5201)のフ ロー試験によりフロー值を測定し、各モルタルのフロー値ができる だけ、140〜200の䉇囲になるようにした。

\section{（i i）曲げ強度・圧縮強度試験}

曲げ強度試験および圧縮強度試験方法はセメントの物理試験方 法(JIS R5201) に準じて行い、 $4 \times 4 \times 16 \mathrm{~cm}$ の供試体を作成しこれ を中央集中荷重で曲げ試験を行った。また圧縮強度試験は、曲げ強 度試験で破断した左右 $2 つ の$ 供試体を用い、戴荷試験を行った。

\section{3. 谪曲け強度モルタルの調合方法}

3.1 シリカフュームの添加率と曲け強度

シリカフュームの添加率とモルタルの曲げ強度の関係を調べる ため表 4 のごとく水結合材比が20、25および30\%のモル夕ルに対し てセメントの内割で0、5、7.5、10および12.5\%のシリカフュー ムを混入して \$2 で述べた方法によりモルタルの緬り混ぜおよび 供試体の作製を行った後、1日間の一次養生に続き、二次養生として $60^{\circ} \mathrm{C}$ の加温養生を 6 日間行った場合と $20^{\circ} \mathrm{C}$ の普通養生を行った場 合について実験を行った。なおシリカフュームの添加率が $0 \%$ で水 結合材比が $20 \%$ のもので砂結合材比が 1.25のときはフロー值が低 く供試体の作製が不能であった。これらのモルタルの水結合材比が $20 \%$ (シリカフューム無添加の場合は $25 \%$ )の場合の調合例を示すと 表 5 のごとくになる。

実験結果は図 $2 \sim 3$ の通りであり、図 2 は曲げ強度試験の結果、 図 3 は圧縮強度試験の結果である。図中の太い実線は加温養生の場
表 3 モルタルの盖生方法

\begin{tabular}{|c|c|c|c|}
\hline \multirow{2}{*}{$\begin{array}{l}\text { 登尘の } \\
\text { 枹營 }\end{array}$} & 一次柆生 & 二次促作 & 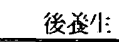 \\
\hline & 1,2 日䦌 & 3,6 HIIII & 3 䢙朾 \\
\hline 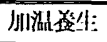 & $201^{\circ} \mathrm{C}$ 渻紧 & 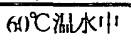 & $210^{\circ} \mathrm{C}$ 水! \\
\hline 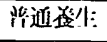 & 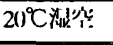 & & C水り \\
\hline
\end{tabular}

表 4 実験要因と水準

\begin{tabular}{|l||l|}
\hline 実験要因 & 実験水準 \\
\hline \hline 水結合材比(W/B) & $20 、 25 、 30$ \\
\hline 沙加工 4 添加率 $(\mathrm{Si} / \mathrm{B})$ & $0 、 5 、 7.5 、 10 、 12.5$ \\
\hline 砂結合材比 $(\mathrm{S} / \mathrm{B})$ & $1.0 、 1.25 、 1,5$ \\
\hline
\end{tabular}

表 5 モルタルの主な調合と強度

\begin{tabular}{|c|c|c|c|c|c|c|c|}
\hline 調合 & 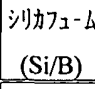 & \begin{tabular}{|l} 
砂結合材 \\
比(S/B)
\end{tabular} & $\begin{array}{l}\text { 水結合材 } \\
\text { 比(W/B) }\end{array}$ & $\begin{array}{c}\text { 混利搂 } \\
(\%)\end{array}$ & $\begin{array}{l}\text { フロー } \\
\text { 値 }(\mathrm{mm}) \\
\end{array}$ & $\begin{array}{l}\text { 曲け強度 } \\
\left(\mathrm{kgf} / \mathrm{cm}^{2}\right)\end{array}$ & $\begin{array}{l}\text { 圧缩強度 } \\
\left(\mathrm{kgf} / \mathrm{cm}^{2}\right)\end{array}$ \\
\hline No.1 & $0 \%$ & 1.5 & $25 \%$ & 2 & 142 & 119 & 882 \\
\hline No.2 & $5 \%$ & 1.25 & $20 \%$ & 4 & 122 & 221 & 1071 \\
\hline No. 3 & $7.5 \%$ & 1.25 & $20 \%$ & 4 & 156 & 249 & 1252 \\
\hline No.4 & $10 \%$ & 1.25 & $20 \%$ & 4 & 139 & 280 & 1340 \\
\hline No. 5 & $12.5 \%$ & 1.25 & $20 \%$ & 6 & 147 & 280 & 1495 \\
\hline
\end{tabular}

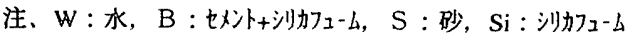

\begin{tabular}{|c|c|}
\hline $\begin{array}{l}-\square-W / B=20 \% \text { 普通養生 } \\
-O-W / B=25 \% \text { 普通生 } \\
-\Delta-W / B=30 \% \text { 普通養生 }\end{array}$ & $\begin{array}{l}\sim \mathrm{W} / \mathrm{B}=20 \% \text { 温水養生 } \\
\sim \mathrm{W} / \mathrm{B}=25 \% \text { 温水荃生 } \\
\sim \mathrm{W} / \mathrm{B}=30 \% \text { 温水盖生 }\end{array}$ \\
\hline
\end{tabular}

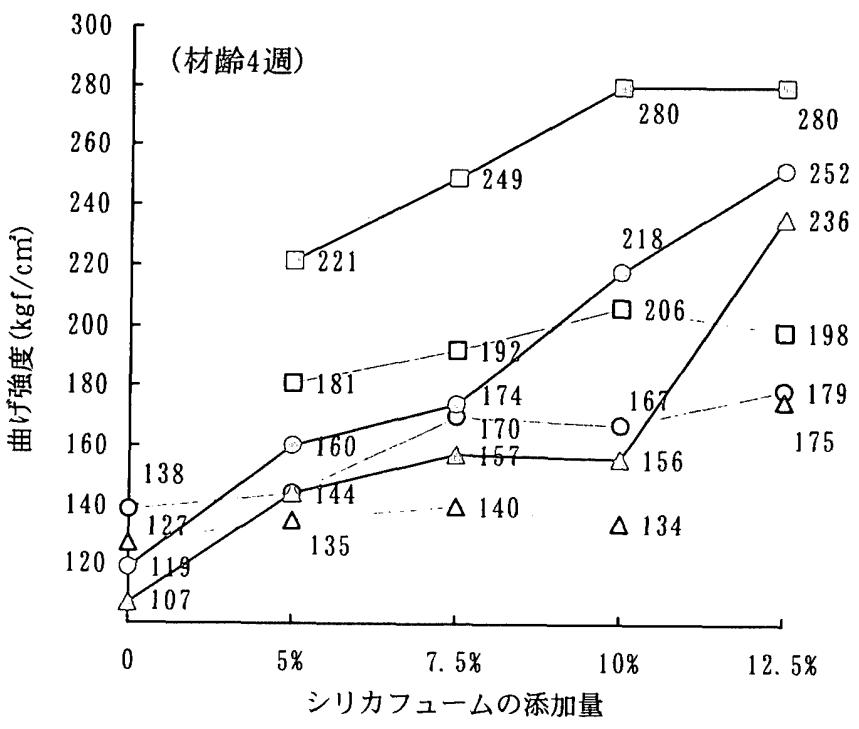

図 2 シリカフュームの添加量と曲げ強度

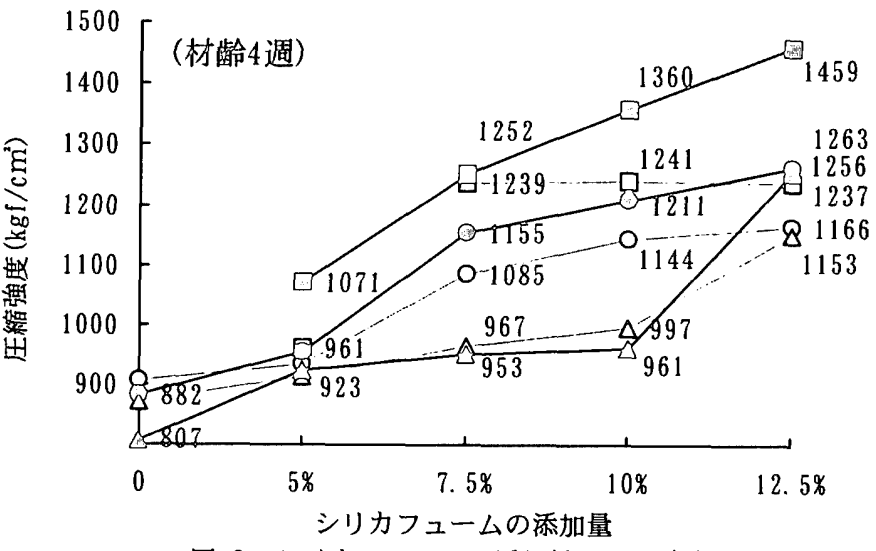

図 3 シリカフュームの添加量と压縮強度 
合であり、細い寒線は普通養生の場合の結果である。これらの結果 より次のごときことがわかった。

普通養生の場合には、シリカフュームを添加することにより曲げ 強度および圧縮強度は增加し、その添加率が多くなるに伴って強度 が增加する。その場合の増加量は曲げ強度で最大 $50 \mathrm{kgf} / \mathrm{cm}^{2}$ 程度で あり、压縮強度で $300 \mathrm{kgf} / \mathrm{cm}^{2}$ 程度である。これをパーセントであ らわすと前者で $30 \%$ 程度、後者でも $30 \%$ 程度であることが分かった。

次に、シリカフュームを添加して一次養生および二次盖生による 加温盖生を行った場合には曲け強度は $120 \mathrm{kgf} / \mathrm{cm}^{2}$ 程度增加し、圧 縮強度は $400 \mathrm{kgf} / \mathrm{cm}^{2}$ 程度增加した。これをパーセンテージで表す と前者の場合は $100 \%$ 程度增加したことになり、後者の場合は $40 \%$ 程度增加したことになる。これは、本研究において開発された養生 方法により、曲げ強度が著しく增加したことを示し、シリカフュー 厶の添加とそれに続く一次羑生および二次荃生の加温盖生が曲け 強度の増加に顕著な効果があることを示しており、しかもその効果 はセメントに対するシリカフュームの添加率が多い程高くなって いる。しかし今回の実験では $280 \mathrm{kgf} / \mathrm{cm}^{2}$ 程度の曲げ強度が得られ ているが、それ以上では頭打ちの傾向が見られた。

\section{2 シリカフュームの総添加量と曲げ強度}

次にこれらの実験結果から水結合材比が $20 \%$ およ゙ $25 \%$ の場合 におけるモルタル $1 \mathrm{~m}^{3}$ 当たりのシリカフュームの総添加量と曲け強 度の関倸について示すと図 4〜5のごとくになる。これらより、水 結合材比 $20 \%$ および $25 \%$ のいずれの場合にも曲け強度はシリカフ ユームの総添加量の增加にほぼ比例して增大するが $280 \mathrm{kgf} / \mathrm{cm}^{2}$ 程 度で頭打ちの傾向が見られた。また、シリカフュームの総添加量が $83 \mathrm{~kg} / \mathrm{m}^{3}$ 以下の場合に、材齢 4 週の曲げ強度が材龄 1 週の曲げ強度よ り低くなっているのは、セメントの固化に伴う体積減少に対応する ためのシリカフュームの量が不足しているためと思われる。従って、 材歯 4 週の曲げ強度を材齢 1 週の曲げ強度より高い値を確保する ためにはシリカフュームの総添加量を $100 \mathrm{~kg} / \mathrm{m}^{3}$ 以上にすることが 必要であると言える。

\section{3 水結合材比 $(\mathbb{W} / \mathrm{B})$ と曲げ強度}

次に、高曲げ強度モルタルの水結合材比 (W/B) と曲げ強度の関係 を調べるため、シリカフュームの添加量を $10 \%$ とし、水結合材比 (W/B)を18，19，20，25，および30\%とした場合の強度実験を行なった。 モルタルの練り混ぜおよび羑生方法は 82 で述べた通りである。

図 6 は実験結果を示したものであって、水結合材比(W/B) が小さ くなると、曲げ強度および圧縮強度は增大する。水結合材比 (W/B) $=20 \%$ 以下では 1 週および 4 週強度とも 280 ないし $295 \mathrm{kgf} / \mathrm{cm}^{2}$ の 曲げ強度が得ることが出来た。またフロー值は水結合材比が小さく なると、表 5 のように小さくなりフロー值が 130 以下の調合は打 ち込むことが困難となり、空隙が多くなり材齢 4 週の曲げ強度もや や低下したものと思われる。

\section{4 砂結合材比 (S/B) と曲け強度}

砂結合材比（S/B） と曲げ強度の関係を調べるため、水結合材比 $(\mathrm{W} / \mathrm{B})=20 \%$ 、シリカフューム $10 \%$ を混入した場合で、砂結合材比 $(\mathrm{S} / \mathrm{B})=0 ， 1 ， 1.25 ， 1.5$ のモタルについて実験を行った。また 義生方法は 82 の通りとした。結果は図 7 に示したとおりである。 この結果より、高曲げ強度モルタルの曲け強度は砂結合材比 (S/B) が1. 25の場合に最も高くなっていることが分かった。

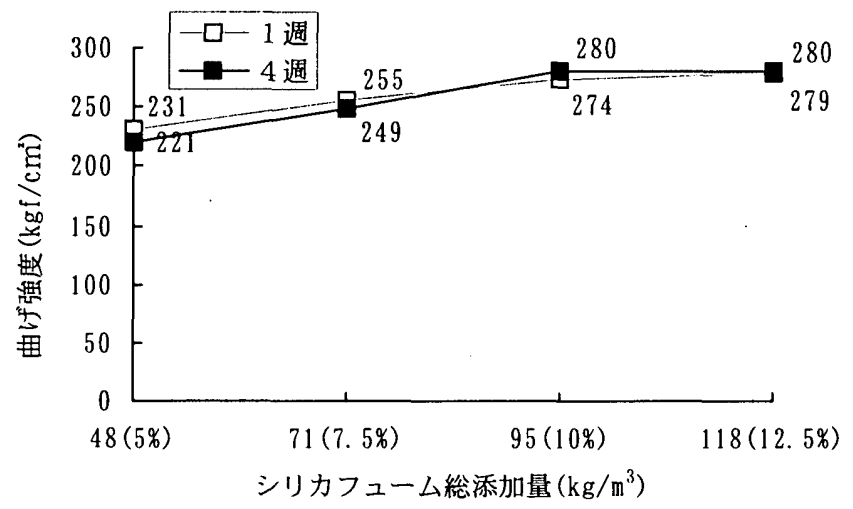

図 4 シリカフューム総添加量と曲げ強度 $(\mathbb{W} / \mathrm{B}=20 \%$ 、温水養生 $)$

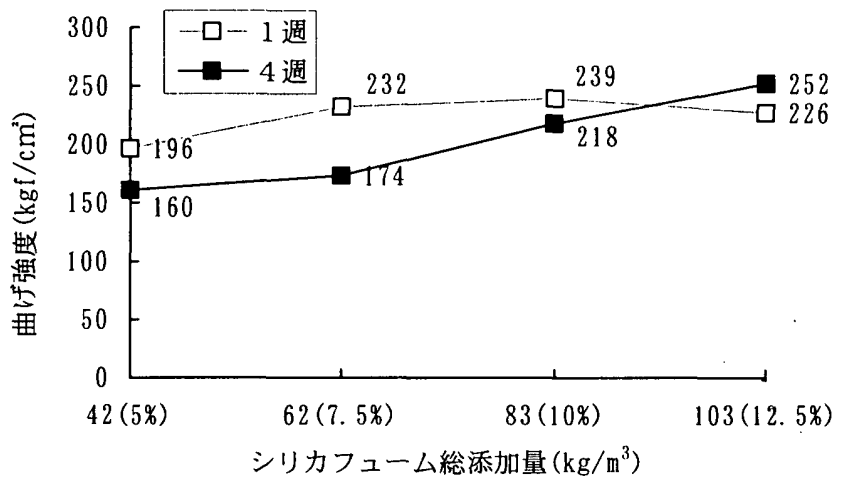

図 5 シリカフューム総添加量と曲げ強度

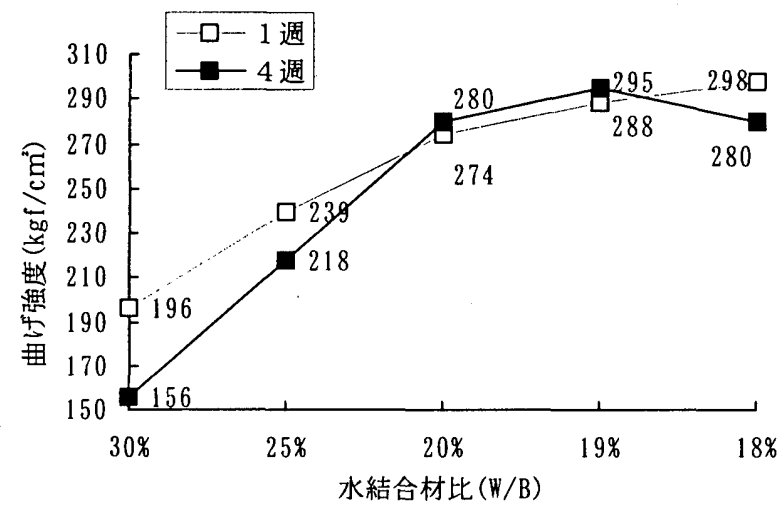

図 6 水結合材比による曲げ強度 （シリカフューム10\%添加時）

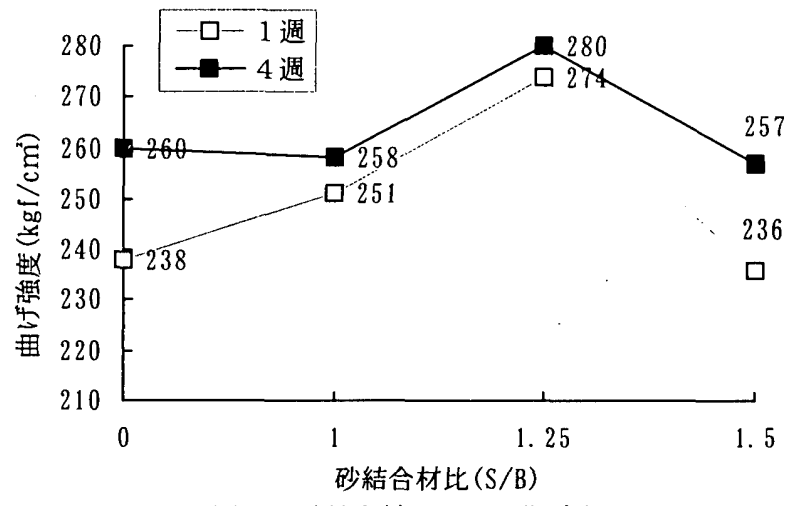

図 7 砂結合材比による曲げ強度 


\section{5 微細砂の使用と曲げ強度}

ここでは高曲げ強度モルタルの曲げ強度の一層の向上を目的と してモルタルの主要構成材料である細骨材の粒径および粒度分布 が曲げ強度に及ぼす影響について検討した。使用した枋料は表 1 に 示したとおりで、セメントは普通ポルトランドセメントを、細骨材 には粒度分布の異なる 4 種類の珪砂を単独または混合して使用し た。モルタルの調合は表 6 のごとく、珪砂 5 号および 6 号に対し、 水結合材比を $20 \%$ および18\%とした計 4 通りの試験体を作製し、普 通盖生と加温養生の違いによる強度変化を測定した。その結果は図 8 のごとく、曲け強度は 1 週および 4 週ともに粒子径の小さい珪砂 6 号を使用したモルタルが高い曲げ強度を示していることが分 かった。これは粒子が細かくなることで細骨材の表面積が増し結合 材一骨材間での加温養生による反応が促進されたためと考えられる。

次に水結合材比 (H/B) を $20 \%$ としてシリカフュームの添加率をセ メントの $10 \%$ とし、細骨材として鹿島産陸砂を用いた場合と鹿島産 陸砂に 7 号珪砂を内割りで $30 \%$ 混合した場合の高曲げ強度コンク リートについてミ2 に述べた方法に従って供試体を作製して強度 実験をおこなった。

実験結果は図 9 に示す通りであって、砂のなかに 7 号珪砂のよう な細かい細骨材を $30 \%$ 混入したものは、材齢 4 週の曲げ強度の伸び が大きく、高い曲げ強度が得られることがわかった。

以上により、高い曲げ強度を得るためにはシリカフュームを添加 し加温盖生するとともに、細骨材には粒子径の小さいものを用いる のが適切であるといえる。

\section{4. 高曲け強度モルタルの諧物徃}

次に、高曲げ強度モルタルの諸物性について、動弾性係数、吸水 率、収縮率、耐衙繁性および耐熱性・耐火性の測定を行った。善生 方法は 82 の加温養生の場合と普通養生の場合の 2 種類について 検討した。動弾性係数については水結合材比 (H/B) $=20 、 25 、 30 \%$ の場合でのシリカフューム5, 7. 5, 10,12.5\%のものについて測定 を行い、また、吸水率、収縮率および衝就試験については水結合材 比 (W/B $)=20 \%$ 、シリカフューム $10 \%$ 添加のものについて測定した。

\section{1 高曲げ強度モルタルの動弾性係数}

動弾性係数は材齢 4 週の圧縮強度の供試体について共鳴法ヤン グ率測定器で測定した。

実験結果は図10aに示す通りで、動弾性係数は $4.5 \times 10^{5}$ ないし 5. $5 \times 10^{5} \mathrm{kgf} / \mathrm{cm}^{2}$ である。また、圧縮強度と動弾性係数の関係は図 $10 \mathrm{a}$ のごとく圧縮強度の增加とともに大きくなっている。温水養生 と普通盖生の動弾性係数を比較すると、温水養生の方が普通養生の 場合よりやや小さい動弾性係数となっており、これは図10bのごと く普通養生のものは曲線となっており、残留歪みが残りやすいため と考えられる。

\section{2 高曲げ強度モルタルの吸水率}

高曲げ強度モルタルの吸水率を調べるため、材齢 4 週の $4 \times 4 \times 16$ $\mathrm{cm}$ のモルタル供試体を $80^{\circ} \mathrm{C}$ の乾燥器内で乾燥させた後に、長さ方 向に水中に平行に深さ $2 \mathrm{~cm}$ まで水中に沈め、その重量変化を24時間 まで測定した。

実験結果は図11に示したとおりで、温水養生したものの吸水率が $0.25 \%$ であり、普通垗生の場合の $0.75 \%$ に対して $1 / 3$ になった。こ
表 6 曲強度と紐骨材の種類との関係を調べたモルタルの調合表

\begin{tabular}{|c|c|c|c|c|c|c|}
\hline No. & 滥学举枌 & 水结合㳔比 & 䏚結合泓比 & 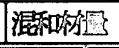 & 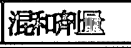 & フロー值 \\
\hline (1) & \multirow[t]{2}{*}{5 号 } & \multirow{2}{*}{$\begin{array}{l}20 \% \\
18 \% \\
\end{array}$} & \multirow{4}{*}{$\mathrm{S} / \mathrm{B}=1.0$} & \multirow{4}{*}{$\mathrm{Si} / \mathrm{B}=0.1$} & \multirow{4}{*}{$\mathrm{AE} / \mathrm{C}=3 \%$} & 300 以上 \\
\hline (2) & & & & & & 171 \\
\hline (3) & \multirow[t]{2}{*}{6 号 } & $20 \%$ & & & & 300 以上 \\
\hline (4) & & $18 \%$ & & & & 167 \\
\hline
\end{tabular}
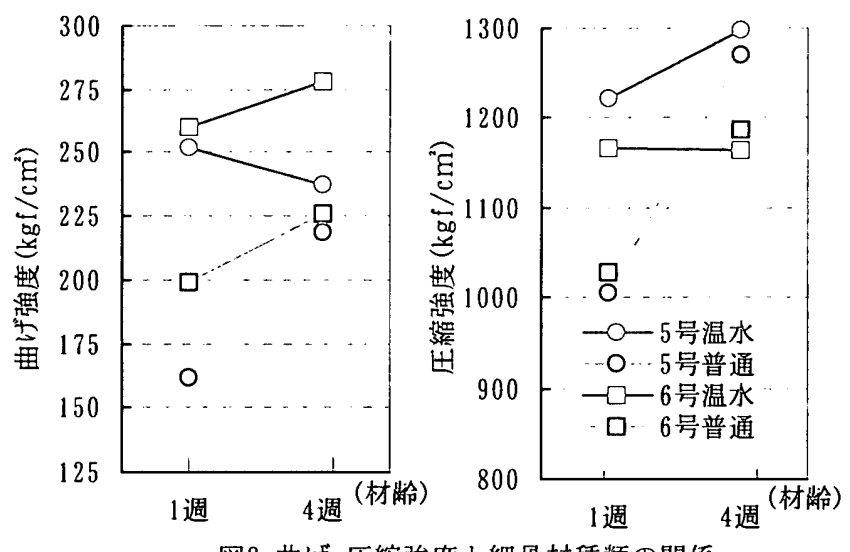

図8曲げ·圧縮強度と細骨材種類の関係
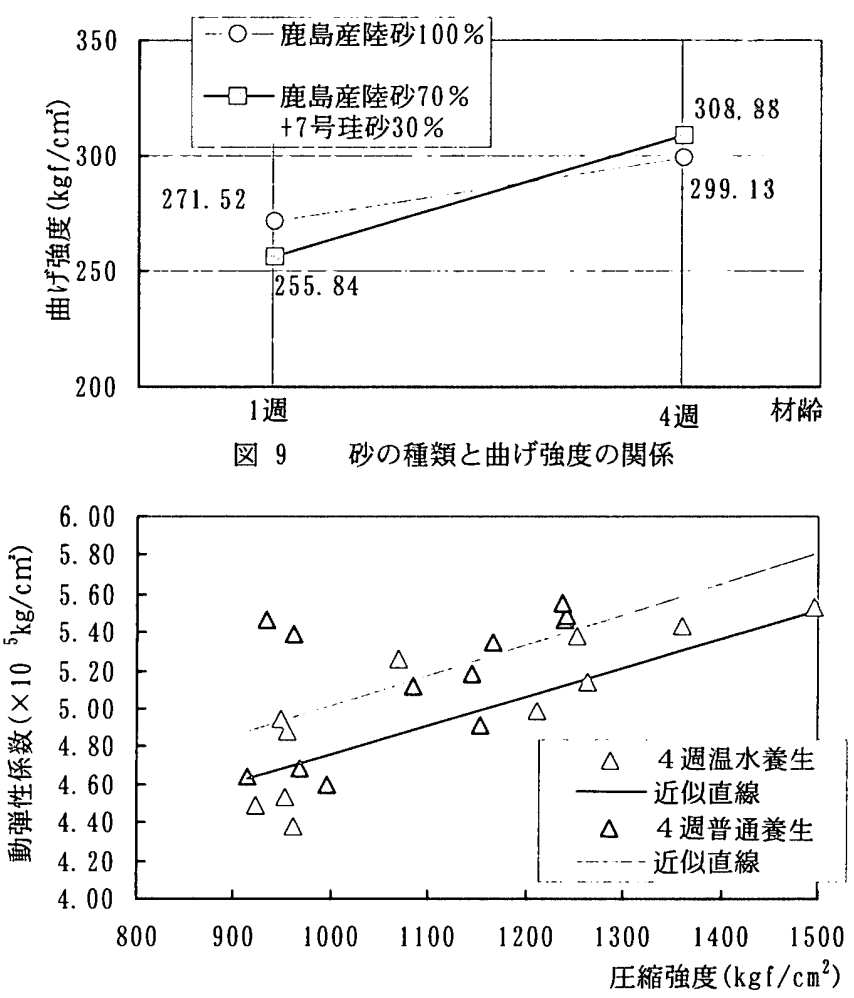

図 $10 \mathrm{a}$ 圧縮強度と動弾性係数

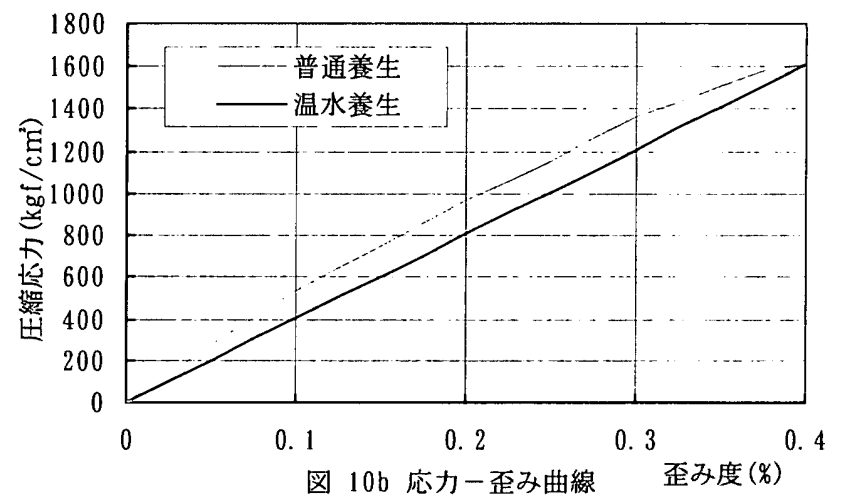


れはシリカフュームの添加と温水養生によりモルタルの組織が緙 密になったためと考えられる。

\section{3 高曲け強度モルタルの収縮率}

高曲げ強度モルタルの収縮率を測定するため温水養生を終了し た $4 \times 4 \times 16 \mathrm{~cm}$ の供試体の両端に $1 \mathrm{~cm}$ 角のガラス板を張り付け、そ

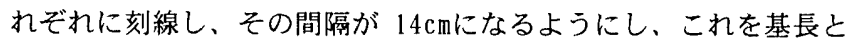
して、1/1000mmの精度のコンパレーターを用いて 1 週間毎に13週ま での長さ変化を測定した。なお供試体は温水美生の後、温度 $20^{\circ} \mathrm{C}$ 湿 度 $60 \%$ の恒温湿室で養生した。

実験結果は図12に示すように、温水養生のものの収縮率は0.02\% 以下となり、普通養生のものは収縮率が $0.06 \%$ となり、前者は後者 の $1 / 3$ であった。これらの収縮率は材齢 2 週あたりから安定してい ることがわかる。これはシリカフュームの添加と加温盖生によりモ ルタルの組織が緻密になったためと考えられる。

\section{4 高曲げ強度モルタルの耐衝撃性}

高曲げ強度モルタルの耐衝撃性を調べるため厚さ $4 \mathrm{~cm}$ で $13.2 \times$ $16 \mathrm{~cm}$ の供試体を作製し図 $13 \mathrm{a}$ のごとく、重さ $1 \mathrm{~kg}$ の茄型おもりを 投下して割れた時の投下高さを評価指標（エネルギー指標）とし て測定した。投下高さは $30 \mathrm{~cm}$ か $40,50, \cdots 100 \mathrm{~cm}$ のピッチで順次 高くして落下させて実験を行った。

実験結果は図 $13 \mathrm{~b}$ のおおりであり、普通養生のものは平均高さ70 $\mathrm{cm}$ で破壊したのに対し、温水養生したものは高さ130 cmの時に破壊 した。これは普通義生のものの1.9 倍であり、シリカフュームを添 加して温水養生したものは耐衝撃性についても高い值となった。こ のことは内部組織がシロキサン結合により微細欠陥の少ないもの になっていることによるものと思われる”。

4.5 高曲け強度モルタルの耐熱性・耐火性

シリカフュームを混入して加温養生することによって得られる 高曲げ強度モルタルの耐熱性および耐火性について検討した。加熱 実験としては比較的低温 $\left(300^{\circ} \mathrm{C}\right.$ 以下)で加熱された場合の耐熱実験 および高温度 $\left(500 \sim 1050^{\circ} \mathrm{C}\right)$ で加熱された場合の耐火実験を行った。 モルタルの調合は表 7 のとおりであり、使用材料、練り混ぜ方法 および養生方法は §2の通りとした。

(1) 実験方法

実験は材齢 6 週となった供試体について、次の二通りの加熱実験 を行った。まず比較的低温 $\left(300^{\circ} \mathrm{C}\right.$ 以下)の加熱実験としては加熱温 度を $200,300^{\circ} \mathrm{C}$ 、加熱時間を 1,3 時間と設定し、電気炉を用いて 加熱した。この場合の加熱速度は $30^{\circ} \mathrm{C} / \mathrm{h}$ とた。次に高温度 $(500 \sim$ $1050^{\circ} \mathrm{C}$ )の加熱実験としてはJIS A1304に規定されている耐火加熱 曲線に準じて耐火試験炉を用いて加熱した。加熱時間は 30 分 $\left(840^{\circ} \mathrm{C}\right)$ 、 一時間 $\left(925^{\circ} \mathrm{C}\right)$ 、二時間 $\left(1010^{\circ} \mathrm{C}\right)$ および 三時間 $\left(1050^{\circ} \mathrm{C}\right)$ とした。こ れらの加熱実験後の圧縮強度試験、曲げ強度試験、長さ変化率の測 定などを行った。

(2) 実験結果と考察

4 週強度および各加熱試験後の圧縮強度および曲げ強度を図14 および図15に示した。また加熱前後の長さ変化率を図16に示した。 これらの結果から次のことが明らかになった。

i）低温加熱の場合

低温加熱 $\left(300^{\circ} \mathrm{C}\right.$ 以下) 試験をしたものの圧縮強度は、図14aのご とくほとんど変化は無かったが、曲げ強度は図15aのごとくシリカ

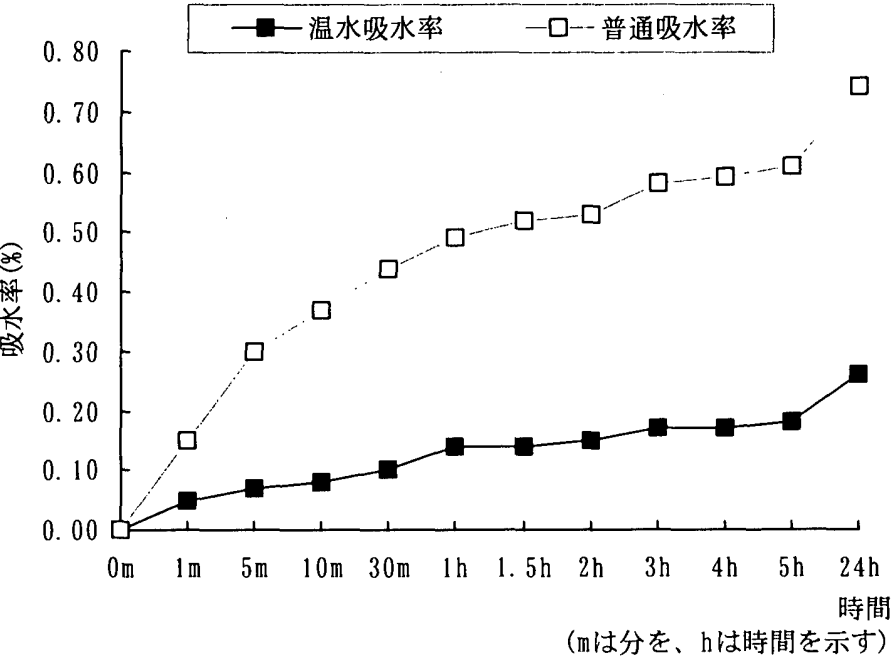

図 11 吸水率の測定結果

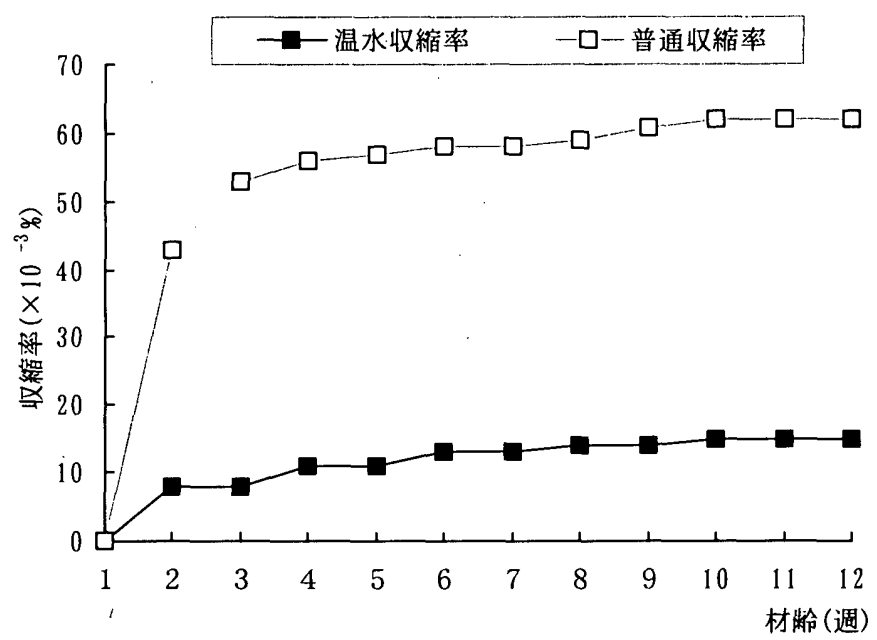

図 12 収縮率の測定結果

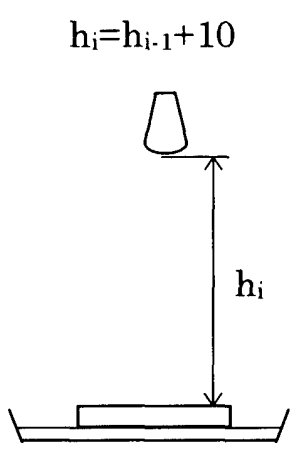

図13a 衝撃試験概念図

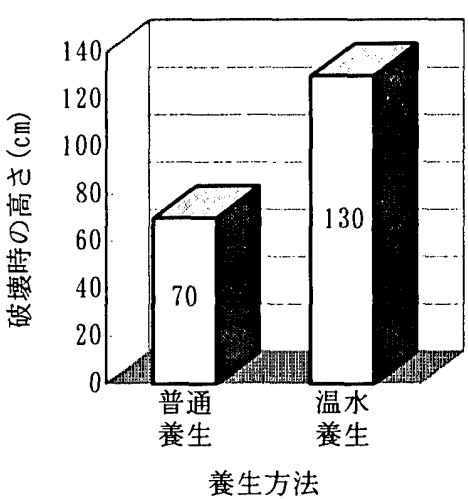

図 13b 衝撃試験結果

\begin{tabular}{|c|c|c|c|c|}
\hline Eル夕タの種類 & $\mathrm{W} / \mathrm{B}$ & $\mathrm{S} / \mathrm{B}$ & 減水剤(\%) & 沜添加率(\%) \\
\hline 晸添加 & 23 & 1.25 & 4 & 10 \\
\hline 泽撫添加 & 25 & 1.5 & 2 & 0 \\
\hline
\end{tabular}


フュームを添加したものは、普通養生および温水養生のいづれの場 合にも低温加熱によって $80 \%$ 程度の曲け強度に低下した。しかし、 その収縮率は、シリカフュームを添加して普通養生したものは、低 温加熱により $0.2 \%$ 程度の収縮率に增大したのに対し、温水養生し たものは0.13\%程度の収縮率で安定している。

以上の結果から低温加熱後のモルタルは、シリカフュームの添加 の有無および養生方法に関係無く、圧縮強度はほとんど低下しない が、曲け強度は、80\%程度に低下する。

また、その収縮率は、シリカフュームを添加して普通養生したも のは、 $0.2 \%$ 程度に增大しているのに対し、温水養生したものは、 0.13\%程度で安定している。

i i）高温加熱の場合 $\left(500 \sim 1050^{\circ} \mathrm{C}\right)$

加熱時間が 30 分 $\left(840^{\circ} \mathrm{C}\right)$ の高温加熱では図 $14 \mathrm{~b}$ のごとく圧縮強度 の低下はほとんど認められないが、加熱時間が 1 時間 $\left(925^{\circ} \mathrm{C}\right)$ では 圧縮強度はいづれも70\%ほどに低下した。さらに加熱時間が 3 時間 $\left(1050^{\circ} \mathrm{C}\right)$ ではシリカフュームを添加し温水養生したものは $50 \%$ 程 度までの低下であったが他は圧縮強度の低下が大きく、特にシリカ フュームを添加し普通養生したものはこの時点で全て爆裂した。な お、シリカフューム無添加のものは $30 \%$ の残存強度を示した。

次に曲け強度については図 $15 \mathrm{~b} の こ ゙ と く$ 加熱時間が 30 分 $\left(840^{\circ} \mathrm{C}\right)$ で急激に低下し、元の強度の約 1/6 になった。また加熱 3 時間（ $1050^{\circ} \mathrm{C}$ )ではシリカフュームを添加して普通養生したものはすべて この時点 $\left(1050^{\circ} \mathrm{C}\right)$ までに爆裂した。しかし、温水養生したものは爆 裂は全く認められなかった。このことは温水養生によりペースト内 部のシリカフュームがゲル状から多量体の結晶に変化したためと 考えられる。

\section{5. まと虭}

以上、シロキサン結合による高曲け強度モルタルの調合方法と諸 物性について検討してきた。その結果、次のごときことが分かった。

（1）高曲け強度モルタルの曲げ強度はシリカフュームの添加率に 比例して増大するが、加温養生することにより曲げ強度は影 著に増加し、元の曲げ強度の 2 倍程度に増大する。

（2）シリカフュームのセメントに対する添加率は10\%程度以上が 適切である。

（3）高曲け強度モルタルの曲け強度はシリカフュームの総混入量 [モルタル $1 \mathrm{~m}^{3}$ に対する混入量 $\left.\left(\mathrm{kg} / \mathrm{m}^{3}\right)\right]$ に比例して増大し、シ リカフュームの混入量を $100 \mathrm{~kg} / \mathrm{m}^{3}$ 以上にすると4週強度が安 定する。

（4）高曲げ強度モルタルの水結合材比は、18〜25\%程度が最適で ある。水結合材比が大きいと細孔量が増大し、曲け強度はあ まり向上しない。また18\%以下のように著しく小さい場合に は締め固めが不十分となりやすく、曲げ強度がやや低下する 可能性がある。

（5）高曲け強度モルタルを得るための適切な砂結合材比が存在し、 今回の実験では砂結合材比は1.25が最適となった。

（6）高曲け強度モルタルの4週強度を向上させるためには、粒度の 小さい砂を使用する方がよく、今回の実験では6号珪砂が効果 的であった。

（7）高曲け強度モルタルの4週強度を增大させるためには、一般の

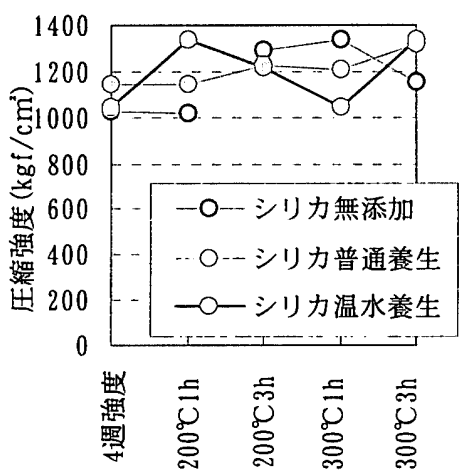

(a)

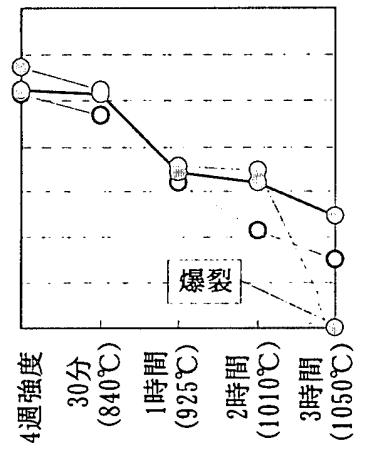

(b)

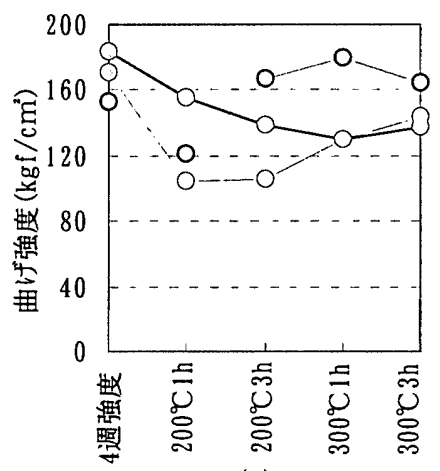

(a)

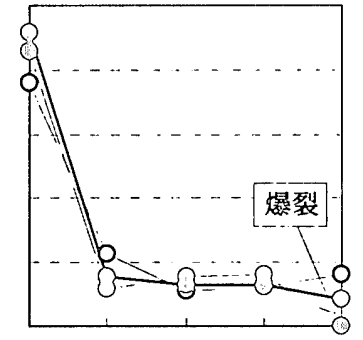

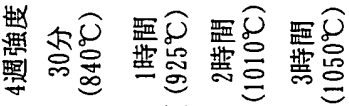

(b)
図15４週曲げ強度と加熱後の強度変化

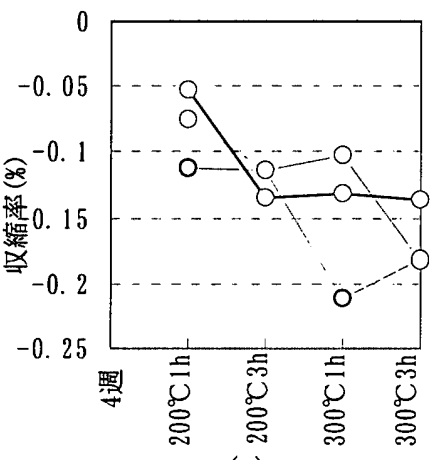

(a)

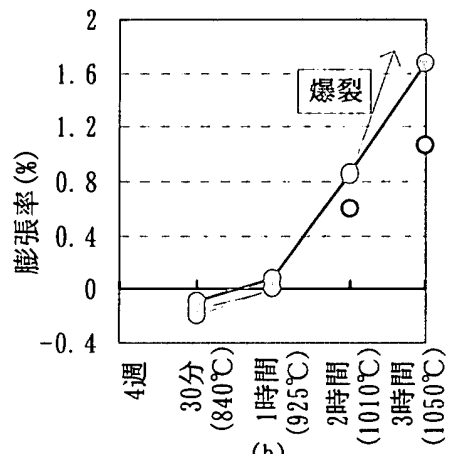

(b)
図16 加熱前後の長さ変化率

川砂等に7号珪砂を $30 \%$ 程度混合するのが効果的である。

（8）高曲げ強度モルタルの弾性係数は $4.5 \times 10^{5} \sim 5.5 \times 10^{5} \mathrm{kgf} / \mathrm{cm}^{2}$ であり普通養生した場合よりやや小さい值となった。

（9）シリカフュームを添加して温水養生した高曲け強度モルタル の吸水率は $0.25 \%$ 以下であり、普通養生の場合の吸水率 $0.75 \%$ の約 $1 / 3$ よさくなっている。

（10）シリカフュームを添加して温水養生した高曲け強度モルタル の収縮率は0.02\%以下であり、普通養生したモルタルが $0.06 \%$ であるのと比較して、約 $1 / 3$ と極めて小さい值となった。

（11）シリカフュームを添加して温水養生した高曲げ強度モルタル の耐衝繁性能は、シリカフュームを添加して普通養生したも のに比較して1.9倍の耐衙䠋性を示した。

（12） 低温加熱時の耐熱性についてはシリカフュームを添加し、普 
通盖生および温水養生したものは圧縮強度はほとんど変化し ないが、曲げ強度は80\%程度に低下した。

（13）低温加熱後のモルタルの収縮率は、シリカフュームを添加し て普通美生したものは、0.20\%に增大するが、温水養生したも のは、0.13\%程度と安定している。

（14）高温加熱時のモルタルの圧縮強度は 30 分加熱で70\%程度に低 下した。3時間加熱の場合ではシリカフュームが無添加のもの は30\%程度に低下し、シリカフュームを添加して普通養生し たものは、この時点までに全て爆裂を起こした。しかし、シ リカフュームを添加して温水㦈生したものは爆裂は起こらず、 $50 \%$ 程度の圧縮強度を保持している。

\section{謝辞}

本研究にあたり、卒業論文として研究を進めていただいた大成建 設(株)の園田博己氏、三井ホームの松本秀司氏、匡 錦標氏および 研究にご協力頂いた相武生コン(株)の方々に謝意を表します。

\section{参考文献}

（1）山本康弘, 本間礼人, 三田紀行: 高曲げ強度セメント・モルタル の研究(養生方法と内部組織に関する研究), 日本建築学会構造 系論文報告集, 第492号, pp. 7〜 14, 1997. 2

（2）山本康弘, 大澤清八, 園田博巳: 高曲け強度フレキシャルモル タルの研究, 日本建築学会大会学術講演梗概集, pp. 467〜 468, 1993. 9

（3）山本康弘，本間礼人，石黒宏: 高曲げ強度モルタルの諸物性に 関する研究, 日本建築学会大会学術講演梗概集, pp. 1473 $1474,1995.8$

（4）三田紀行，山本康弘: 高曲げ強度モルタルの諸物性に関する研 究, 日本建築学会大会学術講演梗概集, pp. 835 836, 1996. 9
（5）三田紀行, 山本康弘, 大澤清八:セメントモルタルのセラミッ ク化に関する基礎的研究, 日本建築学会構造系論文報告集, 第 470 号, pp. 11〜18, 1995. 4

（6）本間礼人, 菅原進一, 高 治遠: コンクリートの爆裂性状に関す る研究, 日本建築学会大会学術講演梗概集，pp. 1393 1394, 1992.8

（7）佐治泰次, 松藤泰典, 吉岡俊二, 石田信一:モルタル試験体によ るシャルピー式衝揧曲げ実験, 日本建築学会大会学術講演梗 概集，(1975.10)，pp. 41，(1977.10)，pp. 223，(1978.9)，pp. 187.

（8）佐治泰次, 松藤泰典: コンクリートの衝椠試験方法.コンク リート工学Vol. 23, No. 3, pp. 73〜81, 1985. 3.

（9）地濃茂雄, 仕入豊和: 練混ぜ時及び荃生初期に高温下にあるコ ンクリートの長期強度增進性の改善方法に関する研究, 日本 建築学会構造系論文報告集, 第350号, pp. 1 8, 1985.4

（10）仕入豊和, 地濃茂雄: コンクリートの初期加熱条件と強度発現 性，日本建築学会大会学術講演梗概集, pp. 149～150, 1981.9

(11) H.Uchikawa and R.Furuta:HYDRATION OF $\mathrm{C}_{3}$ S-POZZOLANAPASTE ESTIMATED BY TRIMETHYLSILYLATION,CEMENT AND CONCRETE RESEARCH,Vol.11,pp.65 78, 1981

(12) B.R.Currell, H.G.Midyley, M.Menteeinos and J.R.Parsonage : A STUDY OF PORTLAND CEMENT HYDRATION BY TRIMETHYLSILYLATION TECHNIQUES, CEMENT AND CONCRETE RESEARCH. Vol.15,pp.889 900, 1985

(13) K.Kato, Y.Fukaya and M.Tanaka:HYDRATION PROPERTY OF VARIOUS CEMENTS UNDER ADIABATIC CONDITIONS,9TH INTERNATIONAL CONGRESS ON THE CHEMISTRY OF CEMENT,pp.124 130,1977 